\title{
Time Management and Environmental Choice in Studies by Students at Universities in Kosovo
}

\author{
Ma.sc. Zymer Tafaj \\ Kosovo Security Force, Isniq - Deçan \\ zymertafaj@hotmail.com \\ Ba.sc. Fatos Turkaj \\ Senator at "Haxhi Zeka" University - Pejë, Dubrav - Deçan \\ fatos.turkaj@unhz.eu \\ Ba.sc. Arsim Kelmendi \\ Kosovo Security Force, Lutogllavë - Pejë \\ arsimi89@hotmail.com
}

Doi:10.5901/ajis.2015.v4n1s2p43

\begin{abstract}
This paper elaborates the topic of time management and environmental choice in studies by students of public and private institutions of higher education in Kosovo. Most students find themselves in front of the biggest challenge that is adapting to student life and achieving success during the studies. To succeed in this field is necessary to manage time effectively. This is especially important for students who often work or deal with other issues such as care for children, family and other responsibilities. Once they find the time to study, they need to provide a place that fills their needs. To do that, they have to make sure if studying place fits with their style and studying preferences. The purpose of this topic is to present how students in Kosovo manage their time during studies in front of many activities for reaching sucess during the studies and finding environment that fits their style of studies. The paper consists by two part, theoretical part that explains theoretical aspect of time managing and environmental choice during studies and relies in secondary and tertiary data using deduction method, where as in part two uses induction method and relies in data collected in ground by survey. During the research work, we used quantitative method where was drafted a survey, and were surveyed by 3100 students from 6 public universities and 3100 students from 20 private universities in Kosovo, in a total from 6200 students. Survey was drafted in that way where answers in our questions help to elaborate basic ideas or the hypothesis of this paper, and through their results to come to verification or denial hypothesis. The derived data are presented in graphical and tabular form. Findings of the paper are that the most of the students even manage activities within the limited time they have no knowledge about the process of time management but they do this activity as a routine duty and the environmental choice they do coincidentally. Time management is a necessary process to do activities on time and reducing pressure from not achieving results in due time. Also environmental choice affects the maximum results during studies.
\end{abstract}

Keywords: Management, time, students, environment, universities

\section{Introduction}

People nowadays are faced with a lot of challenges and problems that are created by a dynamic world with a lot of activities and limited time. Even students as part of this world confront these problems, where their activities are numerous and dynamic, on the other hand, for implementation of activities time and deadlines are limited, and they face multiple pressures, caused by limitations of many sources and the necessity of activities conducting that require immediate solution. Being in these conditions, they definitely should be focused on techniques and ways to manage time, and implementation of works and achieving the goals that are set for certain deadlines. When they will have found the time, their orientation should be done in terms of choosing a study environment that satisfies their preferences in order to feel good, to be more concentrated, vigilant and productive.

Through this work we intend to present the students' attitudes for time management and the selection of study environment. The aim of research paper is: reflection of the way how Kosovo students manage time , this limited source 
in front of many activities, when it is known that the achievement of equilibrium between activities and time is an important factor for success. Also in what environment they prefer more to study .

The paper consists of two parts: theoretical and empirical , whereas methods used in the paper are deductive and inductive. In the theoretical part of the paper that relies on secondary and tertiary data obtained from relevant literature and internet, are used deductive methods. In the second empirical part of the paper which is based on primary data collected in the field through the survey, is used inductive method. To get answers of research questions: How Kosovo students manage time and what environment they choose to study, is used quantitative method, who were surveyed 6200 students from higher education institutions, 3100 students of Public Universities and 3100 students of 20 Private Colleges of Kosovo.

The survey is designed in that way, where answers of questions help to elaborate the basic ideas or hypotheses of the paper and through their results we come to the confirmation or denial of hypotheses. The derived data are presented in graphical and tabular. The samples from which data are taken are managers and workers, who are selected at random. Analytical and comparative methods are applied during our research.

As the main findings of the paper are that the majority of students in higher education institutions in Kosovo have good knowledge about time management and that this knowledge are trying to implement in practice, they also make an effort to chose study environment that fits their preferences. Time management is a necessary process for implementation of activities on the time, and reducing the pressures for not achieving the results in due time also creating a strategy to allocate time to perform successfully. Students are recommended to be careful with these two elements, because time management and study environment choice, affect at their results during studies and if they use them in a good way, it is definitely that the result will be high.

\subsection{The hypothesis of the paper}

$\mathrm{H} 1$ : Majority of students in higher education institutions in Kosovo clarify their schedule and adhere to it, so they do not tolerate dragging of their work because they have clear that their good time management affects to avoid stress and helps to create a strategy to achieve the desired results within the time limit.

$\mathrm{H} 2$ : Majority of students in higher education institutions in Kosovo try to understand their duties and make efforts to achieve them at the right time, so they try to manage their time efficiently ,for the reason to avoid situations with pressure and stressful situations.

H3: Majority of students in higher education institutions in Kosovo try to be maximum motivated and make efforts to create a study environment that is free of disruption like phone calls, numerous conversations and consultations, frequent visits etc. So they try to say no to those things that take their time.

$\mathrm{H} 4$ : Majority of students in higher education institutions in Kosovo try to remove overloading and they plan and split the time for emergencies and unexpected cases, by doing this they try to remove possible barriers to achieve results.

H5: Majority of students in higher education institutions in Kosovo at first they start with difficult works, so during their work they apply Pareto's rule $80: 20$ that means spending $20 \%$ of time to realize $80 \%$ of activities .

H6: Majority of students in higher education institutions in Kosovo assign priorities and try to accomplish them so they assign which activities are more important to them and they start to execute them .

H7: Majority of students in higher education institutions in Kosovo choose the best time to study, most of them prefer to study during the day because they can have more attention and can be more vigilant at studying.

H8: Majority of students in higher education institutions in Kosovo fix up the light at the environment where they study and they prefer more to study at lighted places than dark ones.

H9: Majority of students in higher education institutions in Kosovo fix up the temperature light at the environment where they study and they prefer places that are less warmed because it helps on being more vigilance.

H10: Majority of students in higher education institutions in Kosovo fix up the problem of noise at the environment where they study and they prefer quiet places because they can be more concentrated and feel better .

H11: Majority of students in higher education institutions in Kosovo use more to study alone than in small or large groups because they are more productive.

H12: Majority of students in higher education institutions in Kosovo during study they prefer more to be sit than lying or moving(walking) . 


\section{What Does Education Mean?}

Education and professional training aims to equip with knowledge, skillful practice, skills and competencies that are requested from special professions or in work trade (Kutllovci, 2004, 122). Education is a set of knowledge and habits that are given to the system, according to a program that is at schools and different courses to teach and educate new generations and masses of workers ${ }^{1}$. Education and development is based or focused on the construction of new knowledge and expertise for them to be able to take challenges and new responsibilities (Zeqiri, 2006, 283).

Schools and universities are educational institutions where new generations are taught in organized way2. Every educational institution has its own directors, staff and pupils or students that on their work depends the quality and outcome of that educational institution. In general there are two educational ways (Havolli, 2005, 106):

* Formal Education (concrete job training, technology knowledge, career development, education for the changes that will happen in the future)

* Informal Education (seminars, trainings, workshops, lectures for specific topics).

Education and development has these potential effects: individual effects, group effects, organizations effects and final effects (Kutllovci, 2004, 126-127).

Principles of education and professional training in Kosovo are: comprehensiveness, access, transfer and progress, learning of theatrical and professional practice, present and future economic needs, support of carrier development as integrated part of learning during the life ${ }^{3}$. Whereas levels of education in public and private institutions in Kosovo are4: Preschool, primary school, lower secondary, medium and higher education.

Higher education can be obtained at Universities and High Professional Education Institutions; this can be done in public or private ways. In these Educational Institutions are offered Bachelor, Master and Ph.D.(doctorate) studies, students can choose if they want to do regular or correspondent studies ${ }^{5}$. Higher Education system in Kosovo operates through public universities and private institutions of higher education (colleges, institutions of higher professional schools). Only accredited institutions can offer study programs that can be qualified with diploma ${ }^{6}$.

There are eight (8) accredited public higher educational institutions :University of Prishtina, Peja, Prizreni, Mitrovica, Gjilani, Gjakoa, Kosovo Academy for Public Safety, University of Islamic Studies ${ }^{7}$. Whereas Accredited private institutions are twenty five : College fame, Dardania, Globus, ISPE, AAB, Dukagjini, lliria, Viktory, Universum, Universi, Juridika, UBT, Biznesi, Pjeter Budi,Gjilani, ESLG, Tempulli, Humanistika, Riinvest, Evropian I kosoves, AUK Internacional Prizeren, QEAP Heimerer, Akademia Evulucion and SHLP Design Factory8.

According to the self assessment approved by the Board of Kosovo Accreditation Agency in 2013, number of students in public higher education institutions is 78252, whereas in private higher education institutions is 35966 . Below you will see how students of these higher educational institutions manage the time and chose environment for studying.

\section{Time Management and Choice of Environment for Studying by Students}

Time is a necessary and irreplaceable source to perform duties, it is our most valuable asset, if we lose it than it cannot be back or saved (Tracy, 2014, fq.3). So time is the longest because it presents a continuity measurement, it is shorter because none of us can finish all life duties, time is faster for people that are happy and slower for those who suffer (Zeqiri, 2006, fq.199). Time is objective entirety that can be measured, but our view is subjective (Todorov, Kanev, Angelova, etj, 2003, fq.23).Whereas management shows orientation process of human activities on achievement of set goals, respectively the possibility of interconnected of five functions: planning, organizing, staff, management and control. (Ramosaj, 2007, fq.21). Time management it is a discipline orientated at economic and rational use of time as a valuable

\footnotetext{
1 http://rapitful.blogspot.com/2013/03/cka-eshte-arsimi.html

2 http://adf.ly/238313/banner/http://rapitful.blogspot.com/2012/08/cka-eshte-shkolla.html

${ }^{3}$ http://www.masht-gov.net/advCms/documents/Ligji_per_aftesimin_profesional_2013_alb.pdf

${ }^{4}$ http://www.masht-gov.net/advCms/documents/9.LIGJI_I_ARSIMIT_Ne_KOMUNA2008_03_L068_al_ars.e_kom.pdf

${ }^{5}$ https://www.rks-gov.net/sq-AL/Qytetaret/Edukimi/Pages/ArsimiLarte.aspx

${ }^{6}$ www.akreditimi-ks.org/new/.../536-aka-rvv-2014

${ }^{7}$ http://www.akreditimi-ks.org/new/index.php/sq/accreditation-alb/institucionet-publike

${ }^{8}$ http://www.akreditimi-ks.org/new/index.php/sq/accreditation-alb/2014-11-19-14-36-00/institucionet-private

${ }^{9}$ www.akreditimi-ks.org/new/.../536-aka-rvv-2014 
resource by developing methods and techniques for efficient use of time.

Majority of students find themselves in front of challenge of adaptation to student life and achievement of success on studying, this is important for students who take care about their relatives or other responsibilities and it requires effective management of time. Time management in practice means to do changes in order to discover new opportunities in work and life, and with change we understand will of renounce from those things that prevents us to realize our activities on time. (Todorov, Kanev, Angelova, etc, 2003, page.23) During planning of time students should take in consider who is more important to them: family and friends, school, hobbies and other activities, and they should rank them by priorities. Time planning enables the best time use, elimination of undesired events, minimizing stress and escape from the obligations (Zeqiri, 2006, fq.201). Successful time management requires good planning and compilation of lists , mainly for great or small objective, they should be organized by rank of priorities (Tracy, 2014, fq.3).

Time management should be done for two major reasons: 1 . Because of the lack of knowledge how to manage time, it is the main source of stress and it develops a feeling that we should do more for a short time . 2 Time management enables creation of appropriate strategies to find time to finish all activities successfully, to have a better performance on our work (Zeqiri, 2006, fq.201). Engagement in lectures, the need for learning, preparations and other activities require good arrangement of time. Good arrangement of time requires: set goals, planning , taking decisions , implementation and control (Todorov, Kanev, Angelova, etj, 2003, fq.23).Efficient management of time depends on these important issues : identification of priorities, work order, avoidance of fatigue, the need to avoid time spending with others (Koxhaj, 2006, fq.59). Main principles of managing time are: define goals/objectives, rank all activities, define priorities, make a list of successful things, avoid delaying works for later on, and learn how to say no (Zeqiri, 2006, fq.202).

Even if students have time of the world that wouldn't be enough without good time managing, time management can be achieved in some ways : a) Preparation of daily results that should be achieved, b)Making a list of works that are worthy to be done ,by grouping them in three categories A,B,C, c) Setting the priority works, d) Elimination of duties from group , e) delegation works , f) work with only one duty g) Improving self skills of communication with collaborators (Harold, 1985, fq. 38-39).There are many factors that encumber good arrangement of time: telephone, visitors, discussions, deadlines, documentation, communications, leadership, waiver , vague goals, self discipline, environment etc (Todorov, Kanev, Angelova, etj, 2003, fq.25-27).

Once they have find time to study, students should chose appropriate environment that fulfill their needs. With environment we understand everything around us and that every activity and man's life is connected with it ${ }^{10}$. Environment should fit to their preferences and needs for studying. Every student should choose the right environment for living if it is possible because living is the main reason for social stability, health and quality of human welfare development ${ }^{11}$. A study environment that fulfills students needs for studying, should take in consider factors like study time during the day, light, temperature, noise, way of learning ,the way of staying and movement etc.

\section{Results of the Research - Analysis of Data}

To reach appropriate conclusions, and to fully express statements about problem solution of principal-agent in businesses of the Municipality of Prishtina, was drafted a questionnaire which is focused at business owners and it presents their statement about problem of principal-agent .

Methodology that is used is quantitative method; questionnaire is made in the way to elaborate the base ideas or hypotheses of this work. During the study of 6200 students of Higher Education in Kosovo were surveyed , 3100 students of 6 Public Universities and 3100 students of 20 private Colleges in Kosovo. Through their results we conclude or see the assertion of hypotheses. Issued data are presented in graphic way. The sample data are taken from actual students, who are selected at random. Now let's see achieved results

10 http://ammk-rks.net/repository/docs/broshura_new.pdf

${ }^{11}$ https://www.rks-gov.net/sq-AL/Qytetaret/PronaDheBanimi/Pages/Banimi.aspx 
Time Management

1. Do you clarify and refrain to your schedule because good management of time affect to avoid stress and it helps on creation of a strategy to achieve desired results?

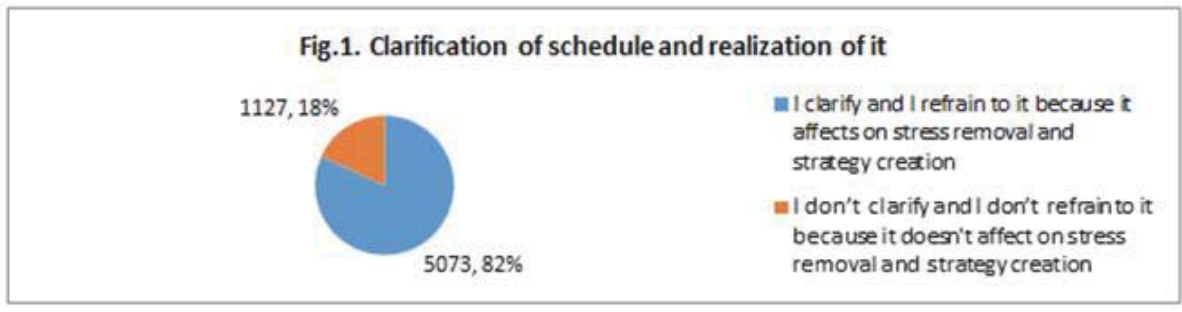

At above figure .1. you can see that majority of students of higher educational institutions or $82 \%$ (5073) of them clarify schedule and try to refrain because they think it affects to avoid stress and it helps on creation of a strategy for time management, those students who answered like this are $52 \%$ or 2642 surveyed that were from public institutions whereas $47.92 \%$ or 2431 surveyed were from private institutions. It can be seen a preponderance of public institutions regarding this attitude. Other half of students who declare for not clarifying schedule is $18 \%$ (1127 surveyed), from this part $40.63 \%$ or 458 surveyed are from public education institutions whereas $59.37 \%$ or 669 surveyed are from private education institutions. This figure results verify our first hypothesis.

2. Do you make sure that you understand the task and do you try to do it on time in way to avoid pressure and stressful situa?

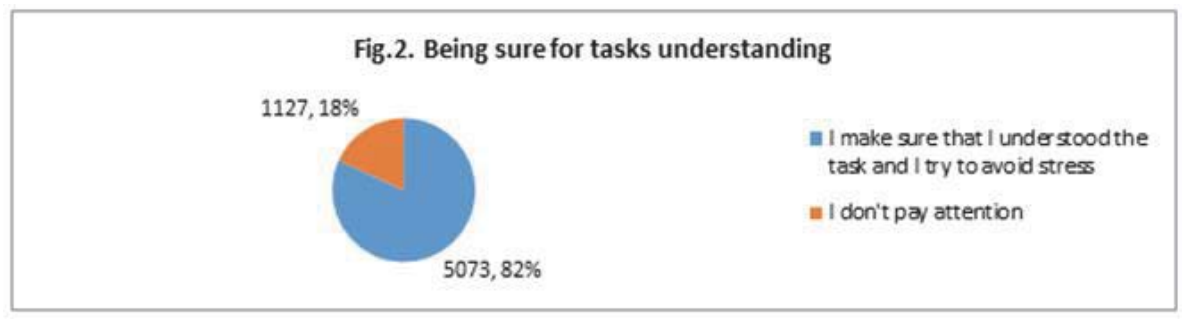

At above figure 2 you can see that majority of students of higher educational institutions or $82 \%$ (5073) of them make sure that they have understood the task in way to avoid stress, those students who answered like this are $52 \%$ or 2642 surveyed were from public institutions whereas $47.92 \%$ or 2431 surveyed were from private institutions . It can be seen a preponderance of public institutions regarding this attitude. Other half of students who declare for not paying attention to the task are 18\% (1127 surveyed), from this part $40.63 \%$ or 458 surveyed are from public education institutions whereas $59.37 \%$ or 669 surveyed are from private education institutions. This figure results verify our second hypothesis.

3. Are you motivated in maximum to implement schedule and do you avoid interruptions?

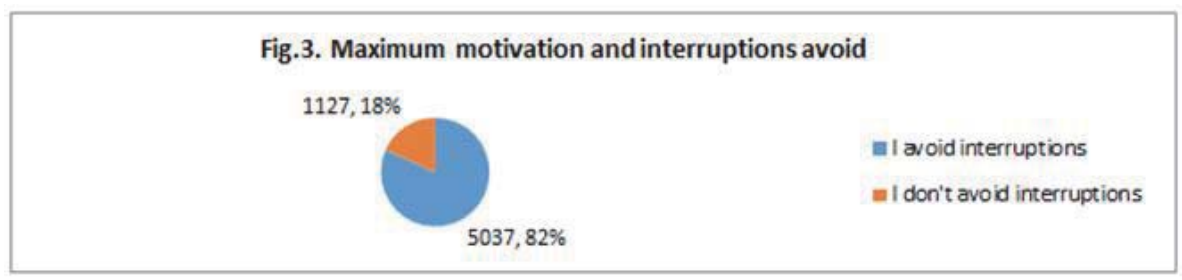

At above figure 3 you can see that majority of students of higher educational institutions or $82 \%$ (5073) of them avoid interruptions so they are maximal motivated , those students who answered like this are $52 \%$ or 2642 they were from public institutions whereas $47.92 \%$ or 2431 surveyed were from private institutions. It can be seen a preponderance of public institutions regarding this attitude. Other half of students who declare for not avoiding interruptions are 18\% (1127 
surveyed), from this part $40.63 \%$ or 458 surveyed are from public education institutions whereas $59.37 \%$ or 669 surveyed are from private education institutions. This figure results verify our third hypothesis.

4. Do you remove overloading by planning emergencies or unexpected cases?

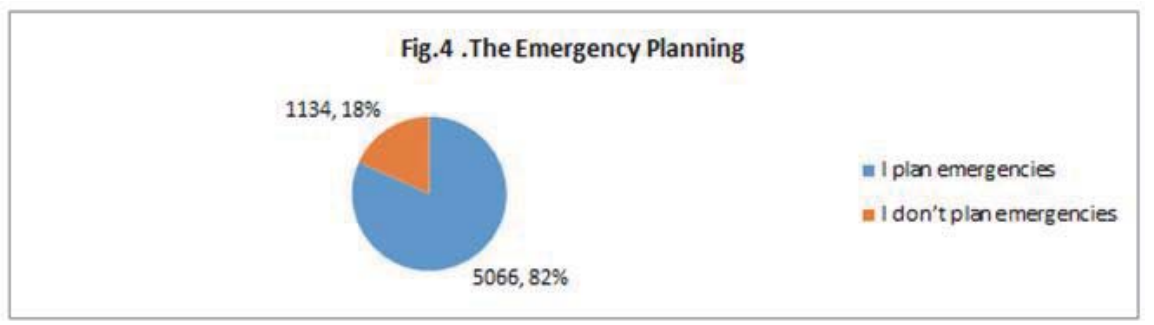

At above figure 4 you can see that majority of students of higher educational institutions or $82 \%$ ( 5066 ) of them plan emergencies and remove overloading, those students who answered like this are $52.07 \%$ or 2638 they were from public institutions whereas $47.93 \%$ or 2428 surveyed were from private institutions. It can be seen a preponderance of public institutions regarding this attitude. Other half of students who declare for not avoiding interruptions are 18\% (1134 surveyed), from this part $40.74 \%$ or 462 surveyed are from public education institutions whereas $59.26 \%$ or 672 surveyed are from private education institutions. This figure results verify our fourth hypothesis.

5. Do you start with difficult work first so do you apply Pareto's rule?

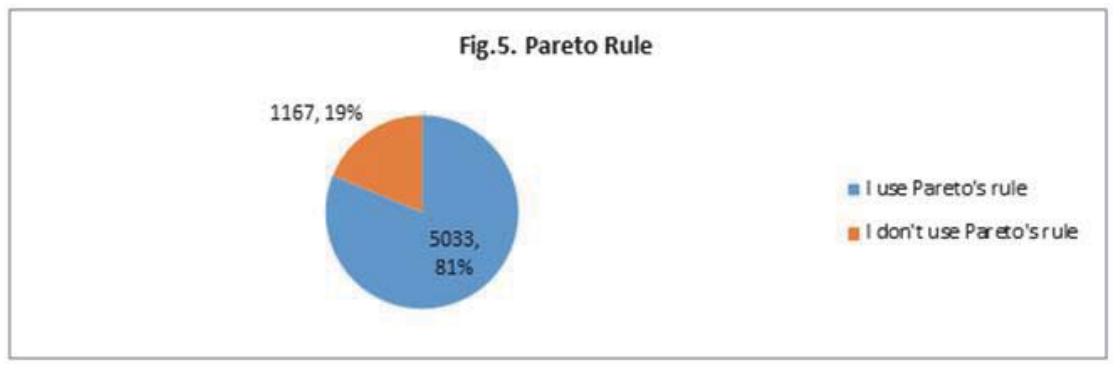

At above figure 5 you can see that majority of students of higher educational institutions or $81 \%$ (5033) of them use Pareto's rule , those students who answered like this are $52.08 \%$ or 2621 they were from public institutions whereas $47.92 \%$ or 2412 surveyed were from private institutions . It can be seen a preponderance of public institutions regarding this attitude. Other half of students who declare for not using Pareto's rule are 19\% (1167 surveyed) ,from this part $41.045 \%$ or 479 surveyed are from public education institutions whereas $58.955 \%$ or 688 surveyed are from private education institutions. This figure results verify our fifth hypothesis.

6. Do you assign priorities and do you achieve them?

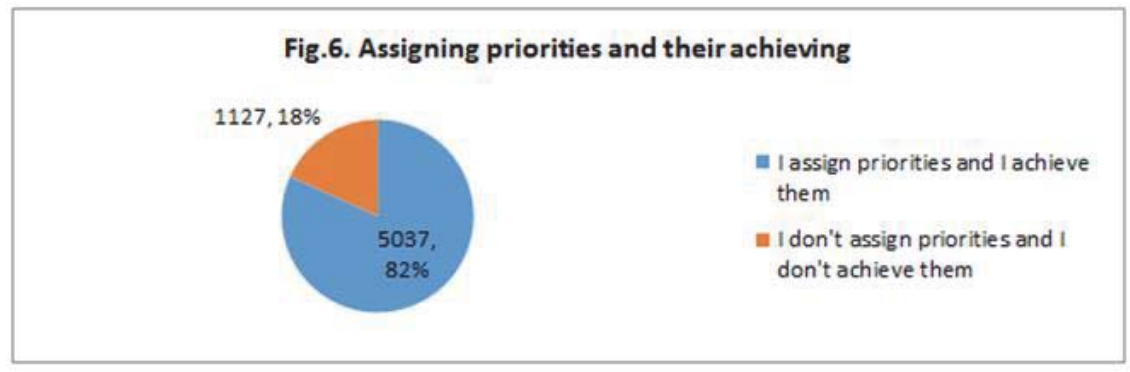

At above figure 6 you can see that majority of students of higher educational institutions or $82 \%$ (5073) of them assign priorities and achieve them, those students who answered like this are $52.08 \%$ or 2642 they were from public institutions 
whereas $47.92 \%$ or 2431 surveyed were from private institutions. It can be seen a preponderance of public institutions regarding this attitude. Other half of students who declare for not assigning priorities and not achieving them are 18\% (1127 surveyed) from this part $40.63 \%$ or 458 surveyed are from public education institutions whereas $59.37 \%$ or 669surveyed are from private education institutions. This figure results verify our sixth hypothesis.

Choose of environment for studying

7. Do you choose study time during the day, and do you prefer to study at day or at night, when are you more attentive and vigilant?

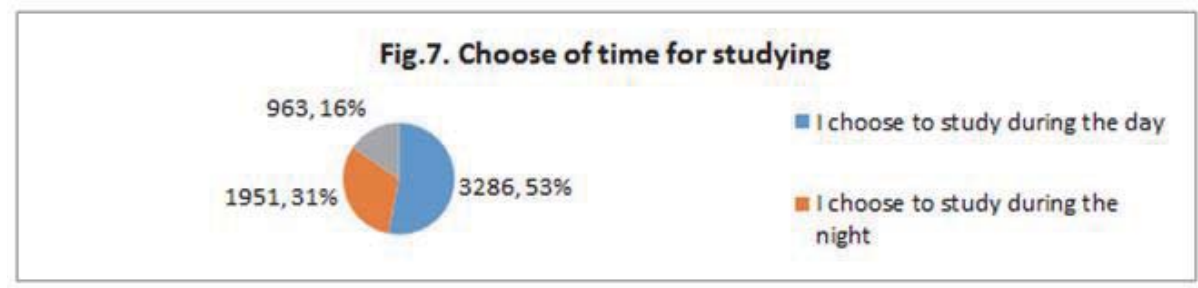

At above figure 7 you can see that majority of students of higher educational institutions or $53 \%$ (3286) of them choose the time and prefer to study during the day , $51.03 \%$ (1677) of them study at public institutions whereas $48.97 \%$ (1609) of them study at private institutions, it is seen a preponderance of public institutions regarding to choose of time for studying during the day. Whereas $31 \%$ (1951) surveyed students choose to study during the night, $49.41 \%$ (964) of them study at public institutions whereas $50.59 \%$ (987) of them study at private institutions, it is seen a preponderance of private institutions regarding to choose of time for studying during the night. In total students who choose time for studying during the day or night are $84 \%$ (5237). From this part 50.43\% (2641) of them study at public institutions whereas $49.57 \%$ (2596) of them study at private institutions, it is seen a preponderance of public institutions regarding to choose of time for studying. Other half of students $16 \%$ ( 963) declare that they don't pay attention to choose time for studying and from this part $52.33 \%$ ( 504) of them study at private institutions whereas $47.66 \%$ (459) of them study at public institutions, it is seen a preponderance of private institutions regarding to not choosing time for studying. This figure results verify our seventh hypothesis.

8. Do you fix up the light at the environment where you study and do you prefer more to study at lighted places or dark places?

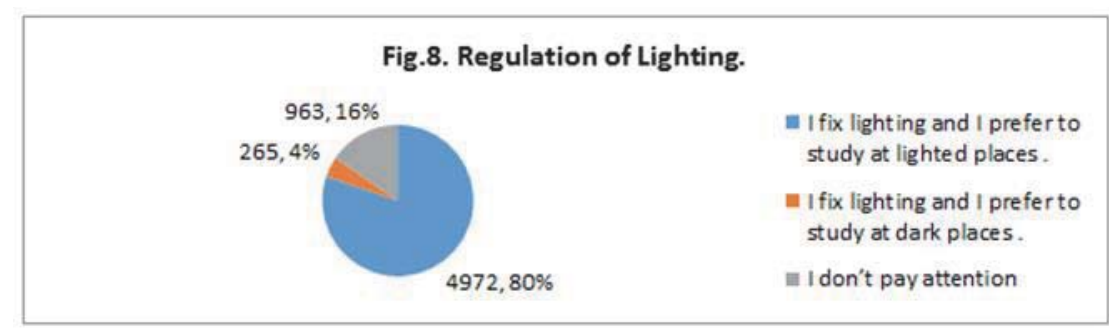

At above figure .8. you can see that majority of students of higher educational institutions or $80 \%$ (4972) of them fix up the light and they prefer to study at lighted places ,50.34\% (2503) of them study at public institutions whereas $49.66 \%$ (2469) of them study at private institutions, it is seen a preponderance of public institutions regarding to regulation of light and studying at lighted places. Whereas $4 \%$ (265) surveyed students prefer to study at dark places, $52.07 \%$ (138) of them study at public institutions whereas $47.93 \%$ (127) of them study at private institutions, it is seen a preponderance of public institutions regarding to study at dark places . In total students that fix up the lighting to study at light or dark places are $84 \%(5237)$. From this part $50.43 \%$ (2641) of them study at public institutions whereas $49.57 \%(2596)$ of them study at private institutions, it is seen a preponderance of public institutions regarding to regulation of light . Other half of students $16 \%(963)$ declare that they don't pay attention to fix up the light , and from this part $52.33 \%(504)$ of them study at private institutions whereas $47.66 \%$ (459) of them study at public institutions, it is seen a preponderance of private 
institutions regarding regulation of light. This figure results verify our eight hypotheses.

9. Do you fix up the temperature at the environment where you study and do you prefer warm places or cold places and where are you more attentive and vigilant .?

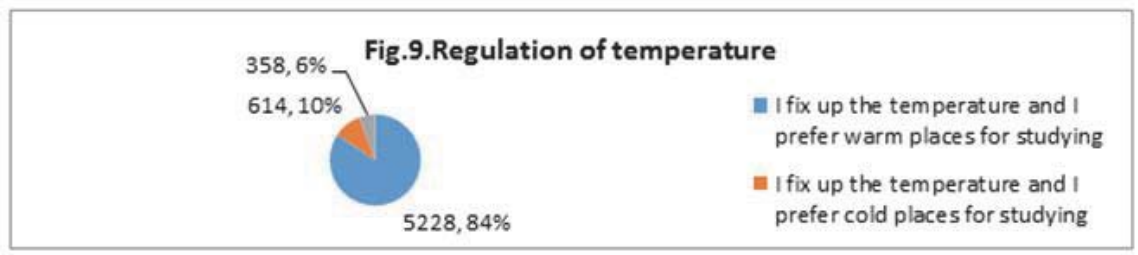

At above figure .9. you can see that majority of students of higher educational institutions or $84 \%$ (5228) of them fix up the temperature and they prefer to study at warm places, $47.89 \%$ (2504) of them study at public institutions whereas $52.11 \%$ (2724) of them study at private institutions, it is seen a preponderance of private institutions regarding to regulation of temperature and studying at warm places. Whereas $10 \%(614)$ surveyed students prefer to study at cold places, $65.30 \%$ (401) of them study at public institutions whereas $34.70 \%(213)$ of them study at private institutions, it is seen a preponderance of public institutions regarding to study at cold places. In total students that fix up the temperature to study at warm or cold places are $94 \%$ (5842). From this part $49.71 \%$ (2905) of them study at public institutions whereas $50.29 \%$ (2937) of them study at private institutions, it is seen a preponderance of private institutions regarding to regulation of temperature. Other half of students $16 \%(963)$ declare that they don't pay attention to fix up the temperature, and from this part $54.56 \%(195)$ of them study at public institutions whereas $45.44 \%$ (163) of them study at private institutions, it is seen a preponderance of public institutions regarding regulation of temperature. This figure results verify our ninth hypothesis.

10. Do you fix up the problems of noise at the environment where you study and do you prefer quite places or it doesn't matter?

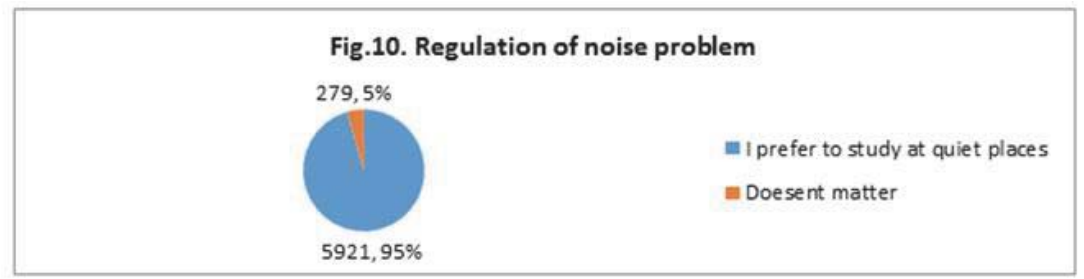

At above figure .10. you can see that majority of students of higher educational institutions or $95 \%$ (5921) of them fix up the problem of noise and they prefer to study at quiet places,49.21\% (2914) of them study at public institutions whereas $50.79 \%$ (3007) of them study at private institutions, it is seen a preponderance of private institutions regarding to regulation of noise and studying at quiet places. Other half of students $5 \%(279)$ declare that they don't pay attention to noise problem, and from this part $66.66 \%(186)$ of them study at public institutions whereas $33.34 \%$ (163) of them study at private institutions, it is seen a preponderance of public institutions regarding to not regulation of noise problem. This figure results verify our tenth hypothesis.

11. Which is your way of study : alone, small groups or large groups?

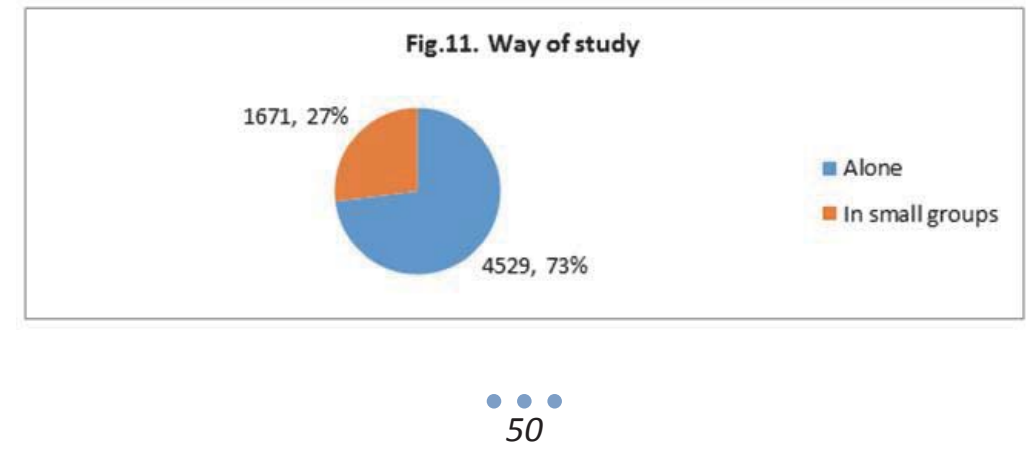


At above figure .11. you can see that majority of students of higher educational institutions or $73 \%$ (4529) of them prefer to study alone, $53.5 \%$ (2423) of them study at public institutions whereas $46.5 \%$ (2106) of them study at private institutions, it is seen a preponderance of public institutions regarding to study alone . Other half of students 27\% (1671) declare that they prefer to study at small groups, and from this part $40.51 \%(667)$ of them study at public institutions whereas $59.49 \%$ (994) of them study at private institutions, it is seen a preponderance of private institutions regarding to study at small groups. This figure results verify our eleventh hypothesis.

12. Which are your movements during the study, do you prefer to be sit, lying or moving (walking)?

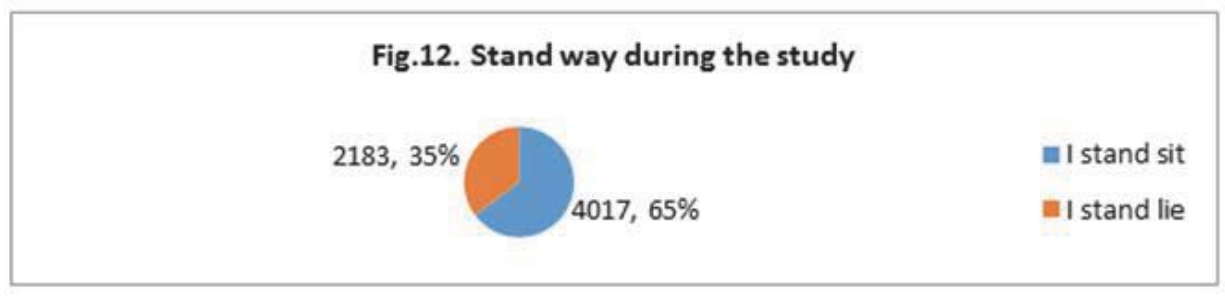

At above figure .12. you can see that majority of students of higher educational institutions or 65\% (4017) of them prefer to study sit, $50.83 \%$ (2042) of them study at public institutions whereas $49.17 \%$ (1975) of them study at private institutions it is seen a preponderance of public institutions regarding to study sit . Other half of students $35 \%(2183)$ declare that they prefer to study lying, and from this part $48.47 \%$ (1058) of them study at public institutions whereas $51.53 \%$ (1125) of them study at private institutions, it is seen a preponderance of private institutions regarding to study lying. It should be mentioned that none of them prefer to study while walking. This figure results verify our twelfth hypothesis.

\section{Conclusions and Recommendations}

\subsection{Conclusions}

Majority of students in higher education institutions in Kosovo clarify their schedule and adhere to it, so they do not tolerate dragging of their work because they know that their good time management affects to avoid stress and helps to create a strategy to achieve the desired results within the time limit.

Majority of students in higher education institutions in Kosovo try to understand their duties and make efforts to achieve them at the right time, so they try to manage their time efficiently, to avoid situations with pressure and stressful situations.

Majority of students in higher education institutions in Kosovo try to be maximum motivated and make efforts to create a study environment that is free of disruption like phone calls, numerous conversations and consultations, frequent visits. So they try to say stop to those activities that take their time.

Majority of students in higher education institutions in Kosovo try to remove overloading and they plan and split the time for emergencies and unexpected cases by doing this they try to remove possible barriers to achieve results.

Majority of students in higher education institutions in Kosovo at first they start with difficult works, so during their work they apply Pareto's rule $80: 20$ that means spending $20 \%$ of time to achieve $80 \%$ of activities .

Majority of students in higher education institutions in Kosovo assign priorities and try to achieve them so they assign which activities are more important and they start to apply them.

Majority of students in higher education institutions in Kosovo chose the best time for studying, most of them prefer to study during the day because they can have more attention and can be more vigilant at studying.

Majority of students in higher education institutions in Kosovo fix up the light at the environment where they study and they prefer more to study at lighted places than dark ones.

Majority of students in higher education institutions in Kosovo fix up the temperature at the environment where they study, they prefer places that are less heated because it helps on being more vigilant.

Majority of students in higher education institutions in Kosovo fix up the problem of noise at the environment where they study and they prefer quiet places because they can be more concentrated and feel better.

Majority of students in higher education institutions in Kosovo use more to study alone than in small or large groups because they are more productive . 
Majority of students in higher education institutions in Kosovo during study they prefer more to be sit than lying or moving (walking).

\subsection{Recommendations}

Majority of students in higher education institutions in Kosovo are recommended to continue in having an attitude about clarifying schedule and adhere to it, and those students who neglected this fact should start applying this during their study activities

Majority of students in higher education institutions in Kosovo are recommended to continue in having an attitude about understanding their tasks and achieve them at the right time, whereas those students who think differently should take immediate measures to understand tasks and to achieve them on time because it helps to remove stressful situations.

Majority of students in higher education institutions in Kosovo are recommended to continue to be maximum motivated and to remove interruptions whereas those students who didn't do this they should immediately start to remove different interruptions because they steal time and prevent to perform tasks on time.

Majority of students in higher education institutions in Kosovo are recommended that during planning to continue to divide time for emergencies and unexpected cases and those who didn't do this, they should do it immediately because this removes overloading and possible interruptions to achieve results .

Majority of students in higher education institutions in Kosovo are recommended that during their planned activities, first to start with difficult works to use Prato's rule, and those who didn't do this, they should start applying it because it affects with $20 \%$ of time to achieve $80 \%$ of activities.

Majority of students in higher education institutions in Kosovo are recommended to continue clarifying priorities and to achieve them and those who didn't do this they should do it because it helps to increase care for important activates.

Majority of students in higher education institutions in Kosovo are recommended to chose the best time for studying at day or night doesn't matter what matters is to be fit with their studying preferences, so when they are more vigilant they will increase results at maximum .

Majority of students in higher education institutions in Kosovo are recommended to fix up the light at the environment where they study in a way that meets their needs for effective work and that affect to them to feel good.

Majority of students in higher education institutions in Kosovo are recommended to fix up the temperature at the environment where they study, in a way that meets their needs for effective and vigilance work that helps them to feel good and to achieve the desired results.

Majority of students in higher education institutions in Kosovo are recommended to fix up the noise problem and to choose places where they can be more concentrated also they should choose in what position they will study: sitting, lying or moving , the one that helps them to be more successful .

Majority of students in higher education institutions in Kosovo are recommended to choose the learning mode that fits to them ,working alone or working in group doesn't matter what matters is to finish duties on time and achieve results.

\section{References}

Havolli, Y., (2005):"Menaxhmenti i resurseve njerëzore, Prishtinë, Riinvest.

Harold B. Crapo, (1985):"Take time to "Wonder" manage more effectively", Data Management.

Koxhaj, A., (2006) : "Aftesitë Menaxheriale", Tiranë, Pegi.

Kutllovci, E., (2004):"Menaxhimi resurseve humane", Prishtin, Universiteti I Prishtinës.

Ramosaj, B. (2007) : "Bazat e Menaxhimit", Prishtinë, Universiteti i Prishtinës.

Todorov, A., D. Kanev, I. Angelova, I. Radev, I. Nikolov, L. Kaneva, M. Dikova, T. Buroxhieva \& J. Georgiev, (2003) : "Menaxhmenti Politik", Shkup, Invest-Trejd.

Tracy,B., (2014) :"Menaxhimi i kohes", Prishtinë, Damo.

Zeqiri, I., (2006) :"Menaxhmenti", Tetovë, Tringa Design.

http://www.akreditimi-ks.org

http://www.ammk-rks.net

http://www.masht-gov.net

http://www.rapitful.blogspot.com

https://www.rks-gov.net

https://www.shqiperia.com 